Bezold-Jarisch reflex ${ }^{6}$ and help to explain the findings of this paper.

C I MEANOCK

Midhurst Medical Research Institute,

Midhurst, W Sussex GU29 0BL

${ }^{1}$ Sleight P, Widdicombe JG. $\mathcal{F}$ Physiol 1965;181: 235-58. 1964;174:323-39.

3 Thorén P. Circulation Res 1977;40:231-7.

Abrahamsson H, Thorén P. Acta Physiol Scand $1973 ; 88: 433-40$.

Res $1975 ; \mathbf{3 6}: 329-35$.

${ }^{6}$ Oberg B, Thorén P. Acta Physiol Scand 1972;85. 145-63.

\section{Sulphinpyrazone in acute myocardial infarction}

SIR,-The administration of sulphinpyrazone early after myocardial infarction was recently shown by $\operatorname{Dr} R$ G Wilcox and others (23 August, $p$ 531) to be accompanied by a significant elevation of serum creatinine and urea. Moreover some of us had reported on four cases of acute renal failure within the first days after starting sulphinpyrazone therapy in patients with a recent myocardial infarction. ${ }^{1}$

The mechanism of this renal functional deterioration has to be clarified. Little evidence supports the hypotheses of intratubular urate precipitation or of an immunologically induced interstitial nephritis. We propose that sulphinpyrazone impairs renal function by inhibiting synthesis of prostaglandins in the kidney, as it does in platelets. ${ }^{2}$

To test this hypothesis, we compared the effect of sulphinpyrazone and of indomethacin -a well-known inhibitor of prostaglandin synthesis-on the urinary excretions of prostaglandins $\mathrm{E}_{2}\left(\mathrm{PGE}_{2}\right)$ and $\mathrm{F}_{2} \alpha\left(\mathrm{PGF}_{2} \alpha\right)$, which reflect the renal synthesis of $\mathrm{PGE}_{2}$ and $\mathrm{PGF}_{2} \alpha^{3}{ }^{3}$ Four healthy male volunteers with normal dietary salt intake collected their 24hour urine during 10 consecutive days. Four doses of sulphinpyrazone $200 \mathrm{mg}$ were taken on days 3 and 4 and three doses of indomethacin $50 \mathrm{mg}$ on days 9 and 10 ; other days served as controls. Other medications, smoking, and sexual activity were withheld. Urinary $\mathrm{PGE}_{2}$ and $\mathrm{PGF}_{2} \alpha$ were measured by radioimmunoassay, as previously described. ${ }^{5}$ When compared with the mean of the values obtained during the two days preceding the drug therapies, the mean urinary $\mathrm{PGE}_{2}$ concentration significantly decreased on the two days of sulphinpyrazone as well as of indomethacin therapy (see accompanying table). Both drugs produced a comparable effect on the urinary $\mathrm{PGE}_{2}$. On the other hand, the mean urinary $\mathrm{PGF}_{2} \alpha$ did not change under sulphinpyrazone therapy, but it was significantly reduced under indomethacin treatment. Neither drug produced a significant change in creatinine clearance; while sulphinpyrazone produced, as expected, an increase in the urate clearance.
The different handling of renal $\mathrm{PGF}_{2 \alpha}$ by the two drugs is not yet well understood. However, a drug such as sulphinpyrazone that reduces the formation of the vasodilating $\mathrm{PGE}_{2}$ in the kidney and does not modify the formation of the vasoconstrictive $\mathrm{PGF}_{2} \alpha$ could in certain clinical situations impair renal haemodynamics and even lead to acute renal failure. In the volunteers studied neither drug produced a consistent change in creatinine clearance. This contrasts with the decrease in renal function when sulphinpyrazone was prescribed soon after infarction reported by Dr Wilcox and his colleagues and by Boelaert et al. ${ }^{1}$ It is possible, however, that sympathoadrenal activation and other vasoconstrictive stimuli characteristic of the postinfarction period lead to renal prostaglandin activation, withdrawal of which could result in decrease in renal blood flow and glomerular filtration. This is now under investigation.

P LIJNEN

L J VERSCHUEREN

A AMERY

Hypertension and Cardiovascular Rehabilitation Unit, University Department of Pathophysiology,
B-3000 Leuven, Belgium

J BOELAERT

R DANEELS M SCHURGERS P VAN EEgheM

Renal Unit,

Algemeen Ziekenhuis St Jan,

B-8000 Brugge, Belgium

${ }^{1}$ Boelaert J, Van Eeghem P, Daneels R, et al. New Engl f Med 1980;303:49.

li M, McDonald WD. $\dot{f}$ Lab Clin Med 1975;89: 868-75.

Frölich JC, Wilson TW, Sweetman BJ, et al. $\mathcal{f}$ Clin Invest $1975 ; 55: 763-70$ Lijnen P, Verschueren LJ, Fagard R, et al. Arch

\section{Salt and blood pressure in Scotland}

SIR,-We read with interest the article by Dr D G Beevers and his colleagues concerning salt and blood pressure in Scotland (6 September, $p$ 641). In the light of our results from a recent study of dietary salt intake and urinary sodium excretion in Swedish women with high and low blood pressure levels ${ }^{1}$ we would like to comment on the results.

In our study 24-hour urine specimens were collected at five different occasions during a three-year period, and in connection with the last three collections food sampling was carried out by applying the duplicate portion technique. ${ }^{2}$ Dietary sodium and potassium were highly correlated $(p<0.001)$ with the corresponding urinary excretion values in the two groups, indicating that the urinary excretion of sodium and potassium very well reflected the dietary intake of these substances. The reproducibility of the five different 24-hour urinary collections was examined by analyses of variance for sodium and potassium excretion. These analyses did not show any significant differences between the five separate measurements of the 24-hour urinary excretion either for sodium or for potassium, despite the rather long period of time between the sampling occasions.

Thus it seems that urinary excretions of salt are highly reproducible and therefore that there is probably no need to "correct" for creatinine excretions. Like the data published by $\mathrm{Dr}$ Beevers and his colleagues, our data on salt intake do not support restriction of salt intake as a means of decreasing blood pressure in the population.

Thomas Thulin

ÁKE NORDÉN

BENGT SCHERSTÉN

Department of Internal Medicine,

University Hospital of Lund,

S-221 85 Lund, Sweden

${ }^{1}$ Thulin T, Abdulla M, Dencher J, et al. Acta Med Scand (in press)

Borgström B, Nordén Å, Åkesson B, Jägerstad M. Scand $\mathcal{F}$ Soc Med (Suppl) 10, 1975;10, suppl.

\section{Prevention or cure for stress-induced} gastrointestinal bleeding?

SIR,-A recent leading article (6 September, p 631) has suggested that impaired coagulation may compound local lesions in cases of stress-induced gastrointestinal haemorrhage. It follows therefore that impaired platelet function may also be disadvantageous.

In order to establish whether cimetidine treatment could influence platelet function we studied its effect on platelet aggregation in vitro. Platelet-rich plasma was prepared from seven healthy volunteers and $400 \mu \mathrm{l}$ incubated for 10 minutes with $50 \mu$ l of various dilutions of cimetidine in physiological saline (see table). $50 \mu \mathrm{l}$ of ADP or adrenaline

Mean percentage fall in optical density at various concentrations of cimetidine

\begin{tabular}{lcccccc}
\hline & \multicolumn{3}{c}{ Final concentration cimetidine $(\mu \mathrm{mol} / \mathrm{l})$} \\
\cline { 2 - 7 } & 0 & 160 & 240 & 320 & 400 & 480 \\
\hline ADP & 76 & 72 & 67 & 53 & 50 & 32 \\
Adrenaline & 74 & 70 & 64 & 52 & 48 & 23 \\
p $^{*}$ & & NS & NS & 0.05 & 0.01 & 0.01 \\
\hline
\end{tabular}

NS = non-significant.

*Paired Wilcoxon's test.

(final concentration 2-5 $\mu \mathrm{mol} / \mathrm{l}$ ) was added to initiate aggregation. Details of methods have been previously described. ${ }^{1}$

Other workers ${ }^{2}$ have shown that the average peak blood levels of cimetidine are $2.8 \mu \mathrm{mol} / \mathrm{l}$ after a $200 \mathrm{mg}$ oral dose and approximately $30 \mu \mathrm{mol} / \mathrm{l}$ after a $100 \mathrm{mg}$ intravenous bolus injection. On the basis of these data our

Urinary prostaglandin $E_{2}$ and $F_{2 \alpha}$ excretion, serum uric acid and creatinine excretion, and creatinine and uric acid clearance before and during sulphinpyrazone or indomethacin (values are means \pm standard errors of means)

\begin{tabular}{|c|c|c|c|c|c|c|c|}
\hline & $\begin{array}{l}\text { Time } \\
\text { (days) }\end{array}$ & $\underset{(\mathrm{nmol} / 24 \mathrm{~h})}{\mathrm{PGE}_{2}}$ & $\underset{(\mathrm{nmol} / 24 \mathrm{~h})}{\mathrm{PGF}_{2 \alpha}}$ & $\underset{(\mathrm{mmol} / \mathrm{l})}{\text { Serum urate }}$ & $\underset{(\mu \mathrm{mol} / \mathrm{l})}{\text { Serum creatinine }}$ & $\begin{array}{l}\text { Creatinine clearance } \\
(\mathrm{ml} / \mathrm{min})\end{array}$ & $\begin{array}{c}\text { Uric acid clearance } \\
(\mathrm{ml} / \mathrm{min})\end{array}$ \\
\hline \multirow{2}{*}{$\begin{array}{l}\text { Control } 1 \\
\text { During sulphinpyrazone }\end{array}$} & \multirow{3}{*}{$\begin{array}{c}\text { Average of } 2 \text { days } \\
\text { Day } 1 \\
\text { Day } 2 \\
\text { Average of } 2 \text { days } \\
\text { Day } 1 \\
\text { Day } 2\end{array}$} & \multirow{3}{*}{$\begin{array}{l}0.66 \pm 0.05 \\
0.35 \pm 0.07 \ddagger \\
0.26 \pm 0.05 \dagger \\
0.76 \pm 0.14 \\
0.26 \pm 0.04 \dagger \\
0.30 \pm 0.07 \dagger\end{array}$} & \multirow{3}{*}{$\begin{array}{l}3.05 \pm 0.50 \\
3.75 \pm 0.82 \\
2.64 \pm 0.66 \\
2.82 \pm 0.27 \\
1.68 \pm 0.18 \dagger \\
1.55 \pm 0.23 \dagger\end{array}$} & $0.37 \pm 0.01$ & $91 \cdot 0 \pm 7 \cdot 1$ & $109 \cdot 8 \pm 3 \cdot 8$ & $9 \cdot 01 \pm 1 \cdot 14$ \\
\hline & & & & $\begin{array}{l}0 \cdot 10 \pm 0.01^{*} \\
0.34 \pm 0.02\end{array}$ & $\begin{array}{l}86 \cdot 6 \pm 4 \cdot 4 \\
88 \cdot 4 \pm 5 \cdot 3\end{array}$ & $\begin{array}{l}122.8 \pm 10.4 \\
113.6 \pm 9.8\end{array}$ & $\begin{array}{l}42 \cdot 17 \pm 1 \cdot 30^{*} \\
9 \cdot 11 \pm 1 \cdot 74\end{array}$ \\
\hline $\begin{array}{l}\text { Control } 2 \\
\text { During indomethacin }\end{array}$ & & & & $0.35 \pm 0.02$ & $91 \cdot 0 \pm 2 \cdot 6$ & $106 \cdot 6 \pm 8 \cdot 0$ & $9 \cdot 02 \pm 0 \cdot 77$ \\
\hline
\end{tabular}

Conversion: SI to traditional units-Urate: $1 \mathrm{mmol}=16 \cdot 8 \mathrm{mg}$; creatinine: $1 \mu \mathrm{mol} / 1=11 \cdot 3 \mu \mathrm{g} / 100 \mathrm{ml}$.

*onversion

$\left.\begin{array}{l}{ }^{*} \mathrm{p}<0.001 \\ \mathrm{p}<0.02\end{array}\right\rangle$ compared with the average of the values obtained during the two days preceding sulphinpyrazone or indomethacin. 